\title{
Adaptation of Australia's Marine Ecosystems to Climate Change: Using Science to Inform Conservation Management
}

\author{
Johanna E. Johnson ${ }^{1,2}$ and Neil J. Holbrook ${ }^{3,4}$ \\ ${ }^{1}$ C2O Consulting, Cairns, QLD 4870, Australia \\ ${ }^{2}$ School of Marine and Tropical Biology, James Cook University, Townsville, QLD 4810, Australia \\ ${ }^{3}$ Institute for Marine and Antarctic Studies, University of Tasmania, Hobart, TAS 7001, Australia \\ ${ }^{4}$ Australia's Climate Change Adaptation Research Network for Marine Biodiversity and Resources, Australia \\ Correspondence should be addressed to Johanna E. Johnson; j.johnson@c2o.net.au
}

Received 4 November 2013; Accepted 26 December 2013; Published 25 February 2014

Academic Editor: Ulisses Azeiteiro

Copyright ( 92014 J. E. Johnson and N. J. Holbrook. This is an open access article distributed under the Creative Commons Attribution License, which permits unrestricted use, distribution, and reproduction in any medium, provided the original work is properly cited.

\begin{abstract}
The challenges that climate change poses for marine ecosystems are already manifesting in impacts at the species, population, and community levels in Australia, particularly in Tasmania and tropical northern Australia. Many species and habitats are already under threat as a result of human activities, and the additional pressure from climate change significantly increases the challenge for marine conservation and management. Climate change impacts are expected to magnify as sea surface temperatures, ocean chemistry, ocean circulation, sea level, rainfall, and storm patterns continue to change this century. In particular, keystone species that form the foundation of marine habitats, such as coral reefs, kelp beds, and temperate rocky reefs, are projected to pass thresholds with subsequent implications for communities and ecosystems. This review synthesises recent science in this field: the observed impacts and responses of marine ecosystems to climate change, ecological thresholds of change, and strategies for marine conservation to promote adaptation. Increasing observations of climate-related impacts on Australia's marine ecosystemsboth temperate and tropical-are making adaptive management more important than ever before. Our increased understanding of the impacts and responses of marine ecosystems to climate change provides a focus for "no-regrets" adaptations that can be implemented now and refined as knowledge improves.
\end{abstract}

\section{Introduction}

Australia's marine ecosystems are typically areas of high biodiversity and important for the ecosystem services they provide to marine industries (e.g., fisheries, aquaculture, and tourism) and people, as well as being iconic features of Australia's national identity. Climate change poses significant challenges for sustainably managing marine species, communities, and ecosystems. Already impacts are being observed in Australia's marine ecosystems due to extreme climate events such as heat waves [1], tropical cyclones [2-4], and flooding $[5,6]$. Further, climate change projections suggest extremes are likely to increase in the future $[7,8]$. The magnitude of impacts on marine ecosystems and whether they can adapt depend on the rate and magnitude of change, the response of marine species and ecosystems, and their resilience to future climate change [9]. Some marine species and ecological communities will be able to respond, while others will require support in order to adapt to increasing climate-related stressors.

The current condition of marine ecosystems plays an important role in determining how they will respond to climate-related disturbances (both acute and chronic) and whether they are able to cope with an increasing rate and magnitude of change. This natural capacity to withstand and recover from disturbances, or resilience $[10,11]$, is often described as the maintenance or return to a stable state [12]. Some projected climate-related changes are within the historic range of variability experienced by marine species. However, the global rate of change is projected to exceed this historic exposure [13]. Natural adaptation and resilience may, therefore, not be sufficient to cope with projected changes 
and may need to be supported by appropriate strategic conservation. The range of strategies available to managers to enhance resilience of marine ecosystems will vary spatially and temporally depending on (i) the response of species, communities, and ecosystems to climate change, (ii) their current condition, (iii) trade-offs with other socioeconomic imperatives, and (iv) existing governance arrangements and management paradigms.

This review provides a synthesis of recent scientific studies relevant to climate change impacts and adaptation of Australia's marine biodiversity and ecosystems and how these can inform conservation management. Adaptation of marine ecosystems to climate change can be reactive or anticipatory, planned or autonomous $[14,15]$, and occur at a range of scales from individuals to complex ecosystems. For most natural systems, adaptation is inherently autonomous. However, adaptation can be assisted by interventions that maximise resilience and reduce harm [16] or realise opportunities associated with the consequences of climate change. Management can influence adaptation and resilience of marine ecosystems in two ways: by acting to reduce the exposure of ecosystems to climate change that reduces condition and undermines resilience or by supporting autonomous adaptation of ecosystems [17]. Conservation management is now undertaking vulnerability assessments to better understand the sources and scales of climate-related impacts and to inform response strategies that build adaptive capacity and enhance resilience [6, 18-20]. Implementing planned adaptations to elicit strategic change in anticipation of a variation in climate requires management regimes that take a systems perspective, particularly across sectoral and jurisdictional boundaries; embraces diversity and change, particularly through accountability, transparency, and being inclusive; and includes coordinated governance [21].

Specifically, this review considers recent climate change science-impacts and thresholds of response for marine species and ecosystems - and how this can focus conservation management on ecosystem-based approaches and planned adaptations. It represents the key findings of a larger initiative to determine whether the research priorities identified in Australia's National Climate Change Adaptation Research Plan for Marine Biodiversity and Resources [22] are being addressed that included a review of marine fisheries [23]. This review provides a synthesis of climate change implications for conservation management and what research focus is needed to inform future management under a changing climate.

\section{Observed Impacts of Climate Change}

The impacts of climate change on Australia's marine ecosystems are already being observed in southeast temperate regions (e.g., [24-26]), the southwest [1,27], and the tropical north (e.g., [28-30]). Recent research has documented impacts in southeast Australia on marine species in response to changing climate drivers, including a decline of giant kelp (Macrocystis pyrifera) by up to $95 \%$ at some sites [31]; a poleward range extension of the long-spined sea urchin
(Centrostephanus rodgersii) into Tasmania [32], poleward shifts of seaweed species along Australia's east and west coasts since 1940 [33], and tropicalization of fish communities [34]. In the southwest, reduced resilience of kelp to disturbances at the northern limit of their range has been documented [35], a marine heat wave in 2011 led to a range contraction in the habitat-forming seaweed Scytothalia dorycarpa [27] and a subsequent shift in community structure towards a depauperate state, as well as a tropicalization of fish communities [1].

Australia's temperate marine regions have high rates of species endemism (e.g., [36]) and with the observed [37] and projected [38] accelerated warming of Australia's southeast marine waters and Tasman Sea, some temperate species are already showing southward (poleward) distributional shifts, while other endemic species will be unable to shift their distribution further south as available habitat is limiting. The expansion of the long-spined sea urchin (C. rodgersii) into Tasmanian waters from New South Wales is altering benthic habitats critical for local species, such as rock lobster and abalone [32]. Southward distributional shifts, attributed to warming temperate oceans, have also been documented for 45 species of fish in southeast Australia since the late 1800s [25] and 16 species of Tasmanian invertebrates [24].

Observed impacts have also been documented in tropical Australia, such as a decline of $11.4 \%$ in coral calcification on the Great Barrier Reef since 1990 [39], declines in fish diversity after climate-related habitat disturbances [40], and reduced adult foraging and chick provisioning of some seabird species during heat waves and after tropical cyclones [41-43]. Stochastic climate-related disturbances, for example, tropical cyclones, floods, and excessive and/or prolonged marine heat waves, have been documented to cause declines in the condition of tropical marine ecosystems. These include documented declines in coral cover on the Great Barrier Reef from $28 \%$ to $14 \%$ since 1985 [28] and declines in seagrass meadows since 2009 with $94 \%$ of sites surveyed classified as being in "poor" or "very poor" condition [29].

Ocean acidification, coupled with local stressors, is expected to impact coralline algae biomass and recruitment, an important component of temperate and subtropical near shore communities [44], with consequences for habitat structure. Reduced calcification will also affect temperate invertebrates, such as early life history stages of sea urchins, compounded by the negative effects of increased temperature on embryo development [45]. Many marine invertebrates are "keystone species" and any impacts on their populations will have consequences for habitat structure and other species that rely on that structure [46].

During the past 15 years, several spatially extensive coral bleaching episodes have occurred on the Great Barrier Reef (GBR) as a consequence of marine heat waves [47, 48]. These climate-related impacts have also been observed in other tropical ecosystems in Australia with marine heat waves causing the first-ever reported bleaching on reefs in the Torres Strait in 2010 [49] and at Ningaloo Reef in Western Australia in 2011 [1]. The ability of coral reefs to recover from bleaching events varies between coral species and among regions, but there is only limited evidence to date that corals can 
adapt to the projected rate and magnitude of increasing sea temperatures combined with ocean acidification [50]. Marine heat waves have also been observed to cause mortality and reduce reproductive success in intertidal and estuarine seagrass species (e.g., [29, 51]).

A long term decline in coral calcification documented on the GBR is postulated to be due to the combined effects of increasing temperature stress and a declining saturation state of seawater aragonite, with a threshold reached in the late 20 th century [52]. Further, studies of coral reefs surviving in naturally low $\mathrm{pH}$ waters of 7.8-8.1 due to volcanic $\mathrm{CO}_{2}$ seeps in Papua New Guinea have documented reductions in coral diversity, recruitment, and abundance of framework building corals, as well as benthic invertebrates and fish [53]. They also documented shifts in competitive interactions between taxa as $\mathrm{pH}$ declines from 8.1 to 7.8 (the change expected if atmospheric $\mathrm{CO}_{2}$ concentrations increase from 390 to $750 \mathrm{ppm}$ [53]). However, coral cover remained constant between $\mathrm{pH}$ 8.1 and $\sim 7.8$, as massive Porites corals dominated (despite low rates of calcification) resulting in a low diversity reef, and reef development ceased below $\mathrm{pH}$ 7.7.

Other tropical species are also experiencing the effects of climate-driven changes in habitats, for example, breeding seabirds that have lost suitable nesting islands due to rainfall changes impacting vegetation and increasing inundation from more intense storms [54, 55], and declines in fish diversity after coral bleaching and tropical cyclone induced habitat disturbances [40]. Impacts on important marine turtle nesting islands are increasingly becoming evident, with elevated sand temperatures biasing hatchling gender ratios toward more females or exceeding thermal mortality thresholds [56, 57]. Habitat range changes have also been documented for coral reefs in Japan, where examination of 80 years of data shows a poleward range expansion of tropical coral species [58].

\section{Ecological Thresholds of Response}

The value of recent observations of climate change impacts is that they can provide insight into thresholds where a relatively small change in external conditions causes a significant change in an ecosystem. When such an ecological threshold has been passed, the ecosystem may no longer be able to return to a stable state and this can lead to rapid declines in ecosystem health [59]. It is for this reason that conservation management is starting to focus on enhancing ecosystem resilience as a key strategy for sustaining marine systems and avoiding these "tipping points" or thresholds of irreversible change. Understanding the environmental conditions that drive thresholds to be crossed and identifying specific communities or habitats that are on the brink of crossing a threshold are critical for being able to successfully manage for resilience.

Studies of ecological thresholds use a range of approaches, including long term studies of ecosystem condition and response [50]; investigations of historic reconstructions using paleorecords [60], ice cores [61], and coral cores [62]; experimental manipulation of environmental conditions to detect thresholds of change [63]; and monitoring of bioindicators coupled with models of ecosystem responses to changing conditions [59]. Most of the recent work on critical thresholds for marine ecosystem change has focused on the impacts of single parameters - in particular, temperature-rather than multiple stressors. The potential for additive, negative, and deleterious synergistic effects will be more severe than indicated from studies of individual stressors [64]. However, for some species antagonistic effects (or reduced stress) are also possible; for example, benthic invertebrate biomass in southeast Australia increased as a result of the interacting effects of fishing, ocean warming, and acidification [65].

An examination of historic climate data and coral reef responses worldwide has shown that mass coral bleaching causing mortality in geographically extensive locations started when atmospheric $\mathrm{CO}_{2}$ concentrations exceeded 320 ppm (with associated ocean warming), and bleaching became sporadic but highly destructive in most reefs at $\sim 340 \mathrm{ppm}$. Coral reefs are projected to be in rapid and terminal decline at $450 \mathrm{ppm}$ (2030-2040 at current rates) from multiple synergies of mass bleaching, ocean acidification, and local environmental impacts [64].

Corals live within $1-2^{\circ} \mathrm{C}$ of their upper thermal limit [66] and the warming of oceans has raised the baseline sea surface temperature closer to their thermal bleaching threshold, so that natural variability is more likely to exceed this threshold [67]. Tropical coral reefs exist in ambient waters of 28.2$34.4^{\circ} \mathrm{C}[68]$ and therefore have higher bleaching thresholds than subtropical corals along Australia's east coast, whose bleaching threshold ranges from 26.5 to $26.8^{\circ} \mathrm{C}$ [69]. Hence, subtropical reefs may be more susceptible to marine heat waves [69] in a region of eastern Australia that is projected to experience accelerated ocean warming.

Recent modelling of increasing air and sea temperature impacts on marine turtle nesting in northern Australia projects that hatchlings will be primarily females at three north Queensland nesting sites by 2070 (Moulter Cay, Milman Island, and Bramble Cay) and by 2030 at Ashmore Island (WA) and Bare Sand Island (Northern Territory). These latter two sites are projected to regularly exceed the upper egg thermal incubating threshold $\left(33^{\circ} \mathrm{C}\right)$ by 2070 , resulting in deformed hatchlings and severe mortality [56].

There is a growing body of work using experimental studies that demonstrate the interactions between multiple climate stressors on abalone and sea urchins [45, 63], corals $[70,71]$, and forams [72]. Studies on the interactive effects of warming and acidification on abalone (Haliotis coccoradiata) and sea urchin (Heliocidaris erythrogramma) found deleterious effects on development (e.g., number of spines produced and skeleton formation) with increasing acidification $(\mathrm{pH}$ 7.6-7.8). An interactive effect between stressors was also documented for sea urchins, with $+2^{\circ} \mathrm{C}$ warming reducing the negative effects of low $\mathrm{pH}$ but the developmental thermal threshold was exceeded at $+4^{\circ} \mathrm{C}$ [63]. A review of marine invertebrate thresholds more broadly shows that all development stages are highly sensitive to warming and larvae are particularly sensitive to acidification [45].

In addition, the proposal that elevated nutrients can lower coral bleaching thresholds [73] has been demonstrated 
experimentally by Wiedenmann et al. [74] who showed that nutrient enrichment (via imbalances) can increase the susceptibility of reef corals to bleaching. This synergistic effect of nutrients and temperature on bleaching response demonstrates the importance of managing local stressors as an effective management strategy to increase the resilience of corals to marine heat waves.

The consequence of passing a critical threshold is that ecosystem condition declines and may not be able to return to a stable state [75]. However, such phase shifts have been shown to be less common than expected [76] or transient [77], demonstrating the dynamic nature of resilient reefs and the need to understand ecological thresholds better. Although, for some marine species and ecosystems, ecological thresholds have been identified, there are limited examples of an Australian marine ecosystem passing such a threshold and undergoing a complete phase shift. International examples of marine phase shifts exist [78]. However, there is still debate whether marine ecosystems operating under a dynamic equilibrium are more likely to exhibit phase shifts (a change in community composition in response to a persistent change in environmental conditions) or exist in alternative stable states (more than one state occurring in the same place and under the same environmental conditions at different times) [79] and if in fact crossing a threshold is necessary to cause such a shift [80].

Adaptive management will be facilitated if the ecological processes with nonlinear behaviours and/or threshold responses to changes in climate drivers can be identified $[59,81]$. Further research on critical thresholds for marine ecosystems and methods for measuring ecosystem dynamics and processes is required for a range of marine ecosystems in Australia, particularly for species of conservation concern and keystone species where climate change impacts have already been observed (Table 1).

\section{Climate Change Implications for Marine Conservation Management}

Current conservation management uses a number of strategies for managing marine resources in Australia, including legislation for extractive activities, regulation of fisheries, international agreements, and marine reserves or marine protected areas (MPAs). Marine reserves (that include no-take areas) can have great benefits for mobile species [82], benthic communities (e.g., [83]), biodiversity conservation [84], and protection of genetic diversity for future adaptation [85]. However, their utility for protecting marine ecosystems from changing climate pressures has been strongly debated. A recent study near Maria Island off Tasmania's east coast showed that marine reserves have the potential to build ecological resilience through mechanisms that promote species and functional stability and resist colonisation by warm water vagrants [34].

The Australian Government has established a system of marine reserves in offshore waters to contribute to the long term conservation of Australia's marine ecosystems, protect marine biodiversity, and maintain resilience. One of the guiding principles when establishing these reserves was to accommodate climate change as far as practicable, using design principles and zoning that promote resilience and adaptation, in particular, accommodating latitudinal or longitudinal movement in ecosystem or species distributions and changes in oceanography, anticipated in response to climate change [86]. The addition of these areas has expanded the total size of Australia's marine reserve estate to 3.1 million $\mathrm{km}^{2}$, making it the largest system of marine reserves globally [86]. However, criticism about the location of these new marine reserves in areas that naturally have low exposure to impacts due to their remoteness or low commercial utility questions their contribution to the real goals of nature conservation, that is, to avoid threats and protect biodiversity [87].

Current marine management clearly identifies the need to protect marine ecosystems in the face of climate change and allow for changing ocean conditions, distributional shifts, and natural adaptation. The utility of MPAs in the face of climate change, therefore, will depend on their location and their ability to protect ecosystem connectivity and promote recovery after climate disturbance. However, the return period of disturbances will be an extrinsic factor that can undermine resilience, and spatial factors strongly influence connectivity. Simulations of coral reef ecosystem connectivity show that climate change is expected to reduce population connectivity by reducing average larval dispersal distance, with naturally fragmented habitats likely to be at higher risk [88]. This study suggests that future conservation efforts consider habitat fragmentation and connectivity when designing MPAs, placing reserves closer together to retain connectivity patterns. As populations become smaller and more isolated due to climate-related habitat loss and fragmentation, it may also be necessary to increase the size of reserves to ensure viable populations are maintained within their boundaries. MPA networks that connect source and sink reefs and consider their role in promoting recovery after climate-related impacts and enhancing resilience to climate change risks will be critical under an uncertain and changing future [89].

In addition, modelling shows that protection of and connectivity to areas expected to have lower exposure to climate drivers are important for enhancing the adaptive capacity of corals, as is protecting genetic diversity [90], which can promote ecosystem recovery post-disturbance [16]. Promoting the conditions that allow for phenotypic adaptation to thermal stress may provide some options for future conservation management, an ability documented in southeast Asia after a significant coral bleaching event in 2010 [91]. However, the rate of projected climate change means this is only a short term option, and long-lived species are unlikely to have the phenotypic plasticity to "keep pace" in the medium- to long term [92].

Whether, in fact, MPAs can offer "climate protection" to marine ecosystems remains to be seen since they are not designed with large-scale distributional shifts, phase shifts, and changing ocean currents in mind. Graham et al. [82] suggest that they offer only limited resilience to climate impacts that are global in scale, since MPAs primarily protect 
TABLE 1: Summary of key observed impacts of climate change in Australian marine ecosystems, (locations of these impacts have been documented), main climate driver(s) implicated, and current management options available to support adaptation.

\begin{tabular}{|c|c|c|c|}
\hline Observed impacts & $\begin{array}{l}\text { Location of documented } \\
\text { impacts }\end{array}$ & Climate driver & Management to support adaptation \\
\hline Giant kelp decline by up to $95 \%$ & Eastern Tasmania & $\begin{array}{l}\text { Increasing ocean } \\
\text { temperature }\end{array}$ & $\begin{array}{l}\text { Maintain ecosystem connectivity; } \\
\text { interventions to replant } \\
\text { communities }\end{array}$ \\
\hline $\begin{array}{l}\text { Changed structure of nearshore } \\
\text { zooplankton communities }\end{array}$ & Eastern Tasmania & $\begin{array}{l}\text { Increasing ocean } \\
\text { temperature }\end{array}$ & Maintain ecosystem connectivity \\
\hline $\begin{array}{l}\text { Poleward range extension of the } \\
\text { long-spined sea urchin causing } \\
\text { habitat changes }\end{array}$ & Eastern Tasmania & $\begin{array}{l}\text { Increasing ocean } \\
\text { temperature }\end{array}$ & $\begin{array}{l}\text { Interventions to rehabilitate } \\
\text { degraded habitats; removal of } \\
\text { locally invasive species; artificial } \\
\text { habitats for displaced species }\end{array}$ \\
\hline Poleward shifts of seaweed species & SE Australia, SW Australia & $\begin{array}{l}\text { Increasing ocean } \\
\text { temperature }\end{array}$ & Maintain ecosystem connectivity \\
\hline $\begin{array}{l}\text { Reduced resilience of kelp to } \\
\text { disturbances at the northern limit of } \\
\text { their range }\end{array}$ & SW Australia & $\begin{array}{l}\text { Increasing ocean } \\
\text { temperature }\end{array}$ & $\begin{array}{l}\text { Maintain ecosystem connectivity; } \\
\text { reduce other stressors on kelp } \\
\text { communities }\end{array}$ \\
\hline $\begin{array}{l}\text { Range contraction of } \\
\text { habitat-forming seaweed and } \\
\text { decline in habitat condition }\end{array}$ & SW Australia & $\begin{array}{l}\text { Increasing ocean } \\
\text { temperature }\end{array}$ & $\begin{array}{l}\text { Maintain ecosystem connectivity; } \\
\text { reduce other stressors on habitats in } \\
\text { decline }\end{array}$ \\
\hline Tropicalization of fish communities & SW Australia, Tasmania & $\begin{array}{l}\text { Increasing ocean } \\
\text { temperature }\end{array}$ & Maintain ecosystem connectivity \\
\hline $\begin{array}{l}\text { Decline of } 11.4 \% \text { in coral } \\
\text { calcification since } 1990\end{array}$ & $\begin{array}{l}\text { Great Barrier Reef, } \\
\text { northeast Australia }\end{array}$ & $\begin{array}{l}\text { Ocean acidification } \\
\text { and increasing ocean } \\
\text { temperature }\end{array}$ & Maintain ecosystem connectivity \\
\hline $\begin{array}{l}\text { Declines in fish diversity after } \\
\text { climate-related habitat disturbances } \\
\text { (coral bleaching and storms) }\end{array}$ & $\begin{array}{l}\text { Great Barrier Reef, } \\
\text { northeast Australia }\end{array}$ & $\begin{array}{l}\text { Marine heat waves } \\
\text { and more intense } \\
\text { storms }\end{array}$ & $\begin{array}{l}\text { Maintain ecosystem connectivity; } \\
\text { reduce other stressors on affected } \\
\text { fish populations during recovery }\end{array}$ \\
\hline $\begin{array}{l}\text { Reduced adult foraging and chick } \\
\text { provisioning of some species of } \\
\text { tropical seabirds }\end{array}$ & $\begin{array}{l}\text { Great Barrier Reef, } \\
\text { northeast Australia }\end{array}$ & $\begin{array}{l}\text { Marine heat waves } \\
\text { and more intense } \\
\text { storms }\end{array}$ & $\begin{array}{l}\text { Reduce other stressors on tropical } \\
\text { seabird populations and breeding } \\
\text { activities }\end{array}$ \\
\hline $\begin{array}{l}\text { Loss of primary seabird nesting } \\
\text { islands }\end{array}$ & $\begin{array}{l}\text { Great Barrier Reef, } \\
\text { northern Australia }\end{array}$ & $\begin{array}{l}\text { Altered rainfall } \\
\text { patterns and more } \\
\text { intense storms (future } \\
\text { sea-level rise) }\end{array}$ & $\begin{array}{l}\text { Reduce other stressors on seabird } \\
\text { nesting islands; rehabilitate } \\
\text { degraded islands; provide artificial } \\
\text { nesting sites }\end{array}$ \\
\hline $\begin{array}{l}\text { Declines in coral cover from } 28 \% \text { to } \\
14 \% \text { since } 1985\end{array}$ & $\begin{array}{l}\text { Great Barrier Reef, } \\
\text { northeast Australia }\end{array}$ & $\begin{array}{l}\text { Marine heat waves } \\
\text { and more intense } \\
\text { storms (and } \\
\text { crown-of-thorn } \\
\text { starfish) }\end{array}$ & $\begin{array}{l}\text { Maintain ecosystem connectivity; } \\
\text { reduce other stressors on coral reefs }\end{array}$ \\
\hline $\begin{array}{l}\text { Declines in seagrass meadows since } \\
2009 \text { with } 94 \% \text { of sites surveyed } \\
\text { classified as being in "poor" or "very } \\
\text { poor" condition }\end{array}$ & $\begin{array}{l}\text { Great Barrier Reef, } \\
\text { northeast Australia }\end{array}$ & $\begin{array}{l}\text { Extreme rainfall } \\
\text { events and more } \\
\text { intense storms }\end{array}$ & $\begin{array}{l}\text { Maintain ecosystem connectivity; } \\
\text { reduce other stressors on seagrass } \\
\text { meadows; rehabilitate severely } \\
\text { degraded habitats }\end{array}$ \\
\hline $\begin{array}{l}\text { Reduced coralline algae biomass } \\
\text { and recruitment }\end{array}$ & $\begin{array}{l}\text { Temperate and tropical } \\
\text { Australian reefs }\end{array}$ & Ocean acidification & Maintain ecosystem connectivity \\
\hline $\begin{array}{l}\text { Reduced calcification of benthic } \\
\text { invertebrates }\end{array}$ & $\begin{array}{l}\text { Experimental-projected } \\
\text { Australia-wide }\end{array}$ & Ocean acidification & $\begin{array}{l}\text { Maintain ecosystem connectivity; } \\
\text { reduce other stressors on benthic } \\
\text { invertebrates }\end{array}$ \\
\hline $\begin{array}{l}\text { Coral bleaching and mortality, and } \\
\text { resultant habitat declines }\end{array}$ & $\begin{array}{l}\text { Great Barrier Reef, } \\
\text { northeast Australia; } \\
\text { Ningaloo Reef, northwest } \\
\text { Australia; Torres Strait, } \\
\text { northern point }\end{array}$ & Marine heat waves & $\begin{array}{l}\text { Maintain ecosystem connectivity; } \\
\text { reduce other stressors on coral reefs }\end{array}$ \\
\hline
\end{tabular}


TABLe 1: Continued.

\begin{tabular}{llll}
\hline Observed impacts & $\begin{array}{l}\text { Location of documented } \\
\text { impacts }\end{array}$ & Climate driver & Management to support adaptation \\
\hline Marine turtle nesting failures & Northern Australia & $\begin{array}{l}\text { Increasing sand } \\
\text { temperature and } \\
\text { inundation (greater } \\
\text { storm surge and } \\
\text { sea-level rise) }\end{array}$ & $\begin{array}{l}\text { Reduce other stressors on turtle } \\
\text { nesting islands; relocate nests; } \\
\text { provide artificial shade at nest sites }\end{array}$ \\
\hline
\end{tabular}

exploited fish and motile invertebrates but their effects on genetic diversity and connectivity are variable and unquantified.

A study of coral reefs in the Seychelles after the 1998 thermal bleaching event showed that reefs in MPAs were most strongly affected by bleaching mortality and that recovery was slow with some sites having $<5 \%$ coral cover seven years after the event [93]. In Australia, bleached reefs on the GBR showed no difference in recovery rates between protected and unprotected areas over a 6- to 10-year period [94]. Similarly, no differences were found in recovery in the seven years following the 1998 bleaching event as a function of protection status [95]. These case studies show that MPAs have had only a limited role in ecosystem recovery from climate-driven disturbances to date, despite their positive effect in promoting recovery from other perturbations, such as crown-of-thorn starfish outbreaks [96]. Therefore, the current spatial and temporal design of MPAs does not appear to provide any advantage to impacted ecosystems recovering from climaterelated disturbances, and the location of MPAs will be critical to their contribution to recovery. Protecting source reefs that are naturally more resilient is a strategy most likely to afford greater recovery potential for themselves and adjacent reefs following disturbances [97]. A more flexible and dynamic approach will need to be part of a suite of tools that can enhance resilience in an uncertain future under a more extreme and variable climate $[82,98]$.

While MPAs may have utility as reference areas to assess future climate change impacts and document new ecosystem structures and function [99], they may also act to enhance resilience [34]. The magnitude of other anthropogenic effects combined with climate change will further test the resilience of marine ecosystems to climate change. For example, the interaction between declining coastal water quality and recent climate-related extreme events (floods and storms) in the GBR has resulted in a deterioration of coastal seagrass meadows since 2009 and species that depend on them, such as dugong and green turtles [100]. Ultimately, effective implementation of MPAs as a resilience strategy will depend on the conservation objectives, the condition of sites, and the future risk of climate impacts [101]. In addition, the complementary management of local and/or regional pressures on marine ecosystems as well as optimal spatial and temporal design of dynamic MPAs to maximise connectivity will also need to be considered if conservation management is to support adaptation to climate change $[64,102]$.

There are many current management strategies employed in Australia to protect marine ecosystems by minimising other human pressures that impact directly marine ecosystem condition and have chronic influences that undermine resilience. These include mining and exploration, shipping and port development, catchment activities that influence marine water quality (urban centers, industry, and agriculture), fishing, and tourism, all of which are managed under different legislative and government levels. At present, management of these pressures is not coordinated or integrated, something that will need to change as the pervasive impacts of climate change increase $[102,103]$.

\section{Adapting Conservation Management under a Changing Climate}

Management of Australia's marine biodiversity under future climate change will require an ecosystem-based approach to conservation [104], explicitly considering the cumulative effects of multiple pressures [44], dynamic ecosystem interactions [105], and ecosystem function [106] as they interact to reduce resilience. For example, the effects of fishing and climate interact because fishing can reduce the biodiversity of marine ecosystems, making them more sensitive to additional stresses, such as ocean warming [107]. Addressing local pressures on marine ecosystems is critical for maintaining healthy marine ecosystems, in order to build resilience to climate change and secure future adaptation options $[17,102]$. Adaptations that address other impacts in the short term and climate change in the long term ("no regrets" or winwin adaptations) [108] provide a response that can be implemented immediately and revised as new information becomes available. Management will therefore need to be coordinated and integrated across sectors to reduce current stressors from deteriorating water quality, overexploitation of marine resources, pollution, and shipping $[64,109,110]$.

The importance of addressing nonclimate stressors is supported by modelling that projects that, even under low $\mathrm{CO}_{2}$ emissions scenarios (e.g., $\sim 540 \mathrm{ppm}$ ), local management maintains and/or restores resilience and increases the chance of reefs remaining coral dominated [111]. Managing marine ecosystems to avoid or reverse such undesirable phase shifts therefore requires an integrated approach through reforms of scientific approaches, policies, governance structures, and management goals [75]. Iwamura et al. [112] used a resource allocation algorithm to prioritise conservation investment that incorporates the stability of ecological regions under future climate change. While focusing on terrestrial ecosystems, their governance approach of accounting for ecological stability to target funding in stable regions and avoid 
phase shifts provides a functional way of incorporating climate change into conservation planning. Essentially, this is a resilience-based approach that advocates protecting the "strong," while improving understanding of ecosystem dynamics to support ecosystem-based management $[75,113]$. Progress is being made in this arena, with a trial in the southern GBR using a series of indicators to identify resilient reefs to prioritise management effort and operationalize a range of local resilience strategies [114], providing a plausible framework for future conservation.

New generation ecosystem models (e.g., multispecies and coupled biophysical) can provide skillful predictions of ecosystem responses to multiple pressures for management and provide information for integrated ecosystem-based management. Models are currently used to focus actions taken by marine management; for example, predictions of marine heat waves known to cause coral bleaching (e.g., [115117]) can trigger responsive management (e.g., [118]), and more such applications will be essential under an uncertain and changing future. The results of recent modelling of ecosystem responses to climate-driven food web changes $[119,120]$ could be incorporated into future ecosystembased approaches that use strategies to focus on locations where declines in primary productivity or communities are predicted.

Although the implications of cascading processes on ecosystem function and resilience remain uncertain, lessons learnt from systems that have lost key functional groups such as top predators [121] and herbivores [122] suggest the need for ecosystem-based approaches that include a food web perspective. Consideration of ecosystem structure and function will likely maximise adaptation to climate change as reductions in marine biodiversity (due to local and regional drivers) can lead to compromised ecosystem resilience to climate change [123].

Marine reserves can protect habitat-specific predatorprey dynamics and have been demonstrated to reinstate trophic dynamics and increase resilience to climate-driven phase shifts in Tasmanian waters [83]. However, recent studies have shown that MPAs do not afford benthic communities protection from climate-related coral bleaching impacts [76, 95]. Their future design should therefore consider both spatial and temporal drivers of change and accommodate inherent uncertainty through greater flexibility. Further, in Australia, where overfishing is not a significant factor that undermines resilience or recovery, the widespread application of MPAs as a response to climate change will need to be complemented by management of chronic nonclimate stressors.

Dynamic MPAs that are designed to be mobile (both spatially and temporally) would allow for climate-related changes in marine environments, with mobile MPAs proposed as an option for protecting species as distributions change [124]. Although there are legal implications of a more flexible conservation approach, many jurisdictions already have the legal frameworks in place to begin to promote and implement actions now with the ability to amend or enact new instruments as experience and knowledge increase [125]. Guidelines for incorporating connectivity into MPAs have been developed $[84,126]$ that outline optimum size, spacing, shape, risk spreading (representation and replication), and connectivity for designing MPA networks that may be more robust in the face of climate change. Although being a legislatively daunting task, the coordinated management of spatially large and connected protected areas that are temporally dynamic and act across sectors is becoming the new paradigm for effective MPAs [126-128] as part of a range of conservation tools [82].

Conservation management will also need to prioritise effort in the face of climate change, and decisions need to be made whether areas of high biodiversity [129], high genetic diversity [92, 106], high stability [112], high resilience [75], or unique ecosystems [106] should be protected. However, it is postulated that the speed at which climate change is impacting marine ecosystems leaves little opportunity for evolutionary processes and survival will be highly dependent upon the natural resistance already in gene pools and the management interventions that can increase resilience [64].

\section{Future Research Needs}

Recent climate change science has sought to better understand how Australia's marine ecosystems are being impacted and are projected to be impacted by climate change and what adaptation strategies are available [130]. However, conservation managers need more information to anticipate the phenology and movements of individual species in response to climate change as well as potential changes to biological communities [131]. Future research needs to support ecosystem-based management by defining critical thresholds and designing methods for measuring ecosystem dynamics and processes, such as phase shifts. This will inform where adaptation management should focus (spatially) on enhancing resilience and employ active conservation to minimise the risks of climate impacts.

While MPAs have utility for conserving important marine resources by reducing extractive activities, their utility as tools for addressing climate change impacts on marine ecosystems is only likely to enhance resilience if complemented by strategies that minimise other pressures, such as deteriorating water quality. The recent consensus for the GBR is that although climate drivers will exacerbate water quality issues, existing pressures need to be addressed to halt the decline of marine ecosystem condition [103]. Science and modelling have a role in developing methods to select the most effective suite of possible strategies and understanding of the spatial and temporal drivers affecting connectivity of marine habitats. Research also needs to investigate whether improving networks of MPAs can connect source and sink reefs to promote recovery after climate-related impacts and if these will actually be effective in reducing long term climate change risks. Improvements in the coupled dynamic representation of the biophysical, economic, and social components of systems and major environmental and anthropogenic drivers will bolster modelling of critical processes whose characteristic spatiotemporal scales span many orders of magnitude (from microbes to ocean basins) [98]. 
Separating marine conservation management from other sectors that impact marine resources, such as catchment and fisheries management, is a paradigm that we need to move away from. Such an integrated approach is being widely applied in the Pacific region through the Ridge to Reef initiative, that aims to integrate water, land, forest, and coastal management to preserve biodiversity and ecosystem services [132]. Ultimately, single sector management is unlikely to see major challenges like climate change addressed and critical research gaps exist to identify and inform multisector integrated management approaches. These gaps are not new; information on multistressor thresholds, multiscale analyses, and synergistic effects has long been identified as challenges for conservation biologists [131].

\section{Conclusions}

Australia's marine ecosystems are areas of high biodiversity, providing important ecosystem goods and services to marine industries and people. These ecosystems are at risk from climate change, and impacts are already being observed in many species and ecological communities around Australia. Recent research efforts reflect the importance of these ecosystems and issues to Australia. However, research gaps still exist and targeted research is needed to inform "no-regrets" adaptations that adopt robust solutions that allow for potential uncertainties together with adaptive approaches that involve monitoring and review as circumstances, conditions, and knowledge change.

A new management paradigm is needed. Climate-aware conservation requires the development of objectives that are not underpinned by a return to historic baselines [124] but rather acknowledge that current equilibrium assumptions are no longer valid. Climate change acts at a range of scalescellular, genetic, species, population, and ecosystem-and managers will need to respond to this by acting over different spatial and temporal scales. The focus of conservation will need to shift from historic species assemblages to an ecosystem-based approach and active adaptation based on potential future climate scenarios [133]. The increasing tropicalization of Australia's east and west coasts will have implications for conservation management, making spatial flexibility, high connectivity, larger management units, and integrated ecosystem-based management essential.

In summary, marine conservation management needs to take an ecosystem-based approach that integrates across sectors and jurisdictions. The temporal and spatial features of MPAs will need to be more dynamic and flexible to consider the observed and projected impacts of climate change such as distributional shifts, habitat declines, and phase shifts. Climate change impacts on Australia's marine ecosystems are currently manifesting in the southeast, southwest, and the northern tropics but are expected to be widespread, increasing the challenge for conservation management.

Climate change provides an unprecedented opportunity to challenge the conventional thinking and evaluate conservation management with a different perspective and a longerterm view. While science is providing important insights into the impacts of climate change on marine resources, effective management strategies need to be responsive, bold, and multilateral. As climate change places additional pressure on already strained marine ecosystems, a new management paradigm needs to consider ecological resilience, crosssectoral integration, long term ecological stability, and facilitate cooperation between jurisdictions. Ultimately, conservation management will need to be ecosystem based and implement "no regrets" adaptations based on the available information in order to sustain Australia's marine ecosystems into the future.

\section{Conflict of Interests}

The authors declare that there is no conflict of interests regarding the publication of this paper.

\section{Acknowledgments}

This review was supported by funding from the Australian Government Department of Climate Change and Energy Efficiency, through the National Climate Change Adaptation Research Facility. The authors thank Clare Brooker for collating the Endnote library and the scientists who have dedicated their effort to investigating the implications of climate change for marine ecosystems. They would like to thank the two anonymous reviewers for their very constructive and helpful reviews and suggestions for this paper. This paper represents a contribution from Australia's Climate Change Adaptation Research Network for Marine Biodiversity and Resources.

\section{References}

[1] T. Wernberg, D. A. Smale, F. Tuya et al., "An extreme climatic event alters marine ecosystem structure in a global biodiversity hotspot," Nature Climate Change, vol. 3, pp. 78-82, 2013.

[2] A. Tobin, A. Schlaff, R. Tobin et al., "Adapting to change: minimising uncertainty about the effects of rapidly-changing environmental conditions on the Queensland Coral Reef Fin Fish Fishery," Final Report to the Fisheries Research \& Development Corporation, Project 2008/103 no. 11, James Cook University, Townsville, Australia, 2010.

[3] K. Osborne, A. M. Dolman, S. C. Burgess, and K. A. Johns, "Disturbance and the dynamics of coral cover on the Great Barrier Reef (1995-2009)," PLoS One, vol. 6, no. 3, Article ID el7516, 2011.

[4] E. Woolsey, S. J. Bainbridge, M. J. Kingsford, and M. Byrne, "Impacts of cyclone Hamish at One Tree Reef: integrating environmental and benthic habitat data," Marine Biology, vol. 159, no. 4, pp. 793-803, 2012.

[5] Climate Commission Secretariat, "The critical decade: extreme events," Department of Climate Change and Energy Efficiency, Australian Government, Canberra, Australia, 2013.

[6] N. A. Marshall, R. C. Tobin, P. A. Marshall, M. Gooch, and A. J. Hobday, "Vulnerability of marine resource users to extreme weather events," Ecosystems, vol. 16, pp. 797-809, 2013.

[7] K. E. Trenberth, "Framing the way to relate climate extremes to climate change," Climatic Change, vol. 115, pp. 283-290, 2012. 
[8] E. C. J. Oliver, S. J. Wotherspoon, M. A. Chamberlain, and N. J. Holbrook, "Projected Tasman Sea extremes in sea surfacetemperature through the 21st Century," Journal of Climate, vol. 27, no. 5, pp. 1981-1998, 2014.

[9] J. B. C. Jackson, “The future of the oceans past," Philosophical Transactions of the Royal Society B, vol. 365, no. 1558, pp. 37653778, 2010.

[10] S. Carpenter, B. Walker, J. M. Anderies, and N. Abel, "From metaphor to measurement: resilience of what to what?" Ecosystems, vol. 4, no. 8, pp. 765-781, 2001.

[11] L. H. Gunderson and L. Pritchard, Resilience and the Behavior of Large Scale Systems, Island Press, Washington, DC, USA, 2002.

[12] M. Nyström, N. A. J. Graham, J. Lokrantz, and A. V. Norström, "Capturing the cornerstones of coral reef resilience: linking theory to practice," Coral Reefs, vol. 27, no. 4, pp. 795-809, 2008.

[13] H. B. Hönisch, A. Ridgwell, D. N. Schmidt et al., "The geological record of ocean acidification," Science, vol. 335, no. 6072, pp. 1058-1063, 2012.

[14] T. R. Carter, M. L. Parry, H. Harasawa, and S. Nishioka, "IPCC Technical Guidelines for Assessing Climate Change Impacts and Adaptations," Department of Geography, University College, London, UK, 1994.

[15] J. B. Smith, "Setting priorities for adapting to climate change," Global Environmental Change, vol. 7, no. 3, pp. 251-264, 1997.

[16] I. M. Côté and E. S. Darling, "Rethinking ecosystem resilience in the face of climate change," PLoS Biology, vol. 8, no. 7, article 5, 2010.

[17] K. R. Anthony and J. A. Maynard, "Coral reefs in the emergency room: continued carbon emissions will increase the need for intensive care," Carbon Management, vol. 2, no. 3, pp. 215-218, 2011.

[18] J. E. Cinner, C. Huchery, E. S. Darling et al., "Evaluating social and ecological vulnerability of coral reef fisheries to climate change," PLoS One, vol. 8, no. 9, Article ID e74321, 2013.

[19] W. B. Foden, S. H. M. Butchart, S. N. Stuart, J.-C. Vie, H. R. Akcakaya et al., "Identifying the world's most climate change vulnerable species: a systematic trait-based assessment of all birds, amphibians and corals," PLoS One, vol. 8, no. 6, Article ID e65427, 2013.

[20] D. J. Welch and J. E. Johnson, "Assessing the vulnerability of Torres Strait fisheries and supporting habitats to climate change," Report to the Australian Fisheries Management Authority, $\mathrm{C}_{2} \mathrm{O}$ Fisheries, Australia, 2013.

[21] M. Lockwood, J. Davidson, M. Hockings, M. Haward, and M. Kriwoken, "Marine biodiversity conservation governance and management: regime requirements for global environmental change," Ocean \& Coastal Management, vol. 69, pp. 160-172, 2012.

[22] B. Mapstone, P. Appleford, K. Broderick et al., "National climate change adaptation research plan for marine biodiversity and resources," National Climate Change Adaptation Research Facility, Gold Coast, Australia, 2010.

[23] N. J. Holbrook and J. E. Johnson, "Australia's marine biodiversity and resources in a changing climate: a review of impacts and adaptation 2009-2012," National Climate Change Adaptation Research Facility, Gold Coast, Australia, 2012.

[24] N. R. Pitt, E. S. Poloczanska, and A. J. Hobday, "Climatedriven range changes in Tasmanian intertidal fauna," Marine and Freshwater Research, vol. 61, no. 9, pp. 963-970, 2010.

[25] P. R. Last, W. T. White, D. C. Gledhill et al., "Long-term shifts in abundance and distribution of a temperate fish fauna: a response to climate change and fishing practices," Global Ecology and Biogeography, vol. 20, no. 1, pp. 58-72, 2011.

[26] T. Wernberg, B. D. Russell, P. J. Moore et al., "Impacts of climate change in a global hotspot for temperate marine biodiversity and ocean warming," Journal of Experimental Marine Biology and Ecology, vol. 400, no. 1-2, pp. 7-16, 2011.

[27] D. A. Smale and T. Wernberg, "Extreme climatic event drives range contraction of a habitat forming species," Proceedings of the Royal Society B, vol. 280, pp. 201228-201229, 2013.

[28] G. De'ath, K. Fabricius, H. Sweatman, and M. Puotinen, "The 27 year decline of coral cover on the GBR and its causes," Proceedings of the National Academy of Sciences, vol. 109, pp. 1799517999, 2012.

[29] L. J. McKenzie, C. Collier, and M. Waycott, "Reef Rescue Marine Monitoring Program: inshore seagrass annual report 2010/2011," Tech. Rep., Fisheries Queensland, Cairns, Australia, 2012.

[30] A. Thompson, P. Costello, J. Davidson et al., "Reef Rescue Marine Monitoring Program," Report of AIMS ActivitiesInshore Coral Reef Monitoring 2011. Report for Reef and Rain Forest Research Centre, Australian Institute of Marine Science, Townsville, Australia, 2011.

[31] C. R. Johnson, S. C. Banks, N. S. Barrett et al., "Climate change cascades: shifts in oceanography, species' ranges and subtidal marine community dynamics in eastern Tasmania," Journal of Experimental Marine Biology and Ecology, vol. 400, no. 1-2, pp. 17-32, 2011.

[32] S. D. Ling, C. R. Johnson, S. D. Frusher, and K. R. Ridgway, "Overfishing reduces resilience of kelp beds to climate-driven catastrophic phase shift," Proceedings of the National Academy of Sciences of the United States of America, vol. 106, no. 52, pp. 22341-22345, 2009.

[33] T. Wernberg, B. D. Russell, M. S. Thomsen et al., "Seaweed communities in retreat from ocean warming," Current Biology, vol. 21, no. 21, pp. 1828-1832, 2011.

[34] A. E. Bates, N. S. Barrett, R. D. Stuart-Smith, N. J. Holbrook, P. A. Thompson, and G. J. Edgar, "Resilience and signatures of tropicalization in protected reef fish communities," Nature Climate Change, vol. 4, pp. 62-67, 2014.

[35] T. Wernberg, M. S. Thomsen, F. Tuya, G. A. Kendrick, P. A. Staehr, and B. D. Toohey, "Decreasing resilience of kelp beds along a latitudinal temperature gradient: potential implications for a warmer future," Ecology Letters, vol. 13, no. 6, pp. 685-694, 2010.

[36] K. Benkendorff and R. Przeslawski, "Multiple measures are necessary to assess rarity in macro-molluscs: a case study from southeastern Australia," Biodiversity and Conservation, vol. 17, no. 10, pp. 2455-2478, 2008.

[37] K. R. Ridgway, "Long-term trend and decadal variability of the southward penetration of the East Australian Current," Geophysical Research Letters, vol. 34, no. 13, Article ID L13613, 2007.

[38] C. Sun, M. Feng, R. J. Matear et al., "Marine downscaling of a future climate scenario for Australian boundary currents," Journal of Climate, vol. 25, no. 8, pp. 2947-2962, 2012.

[39] G. De'ath, K. E. Fabricius, and J. M. Lough, "Yes-coral calcification rates have decreased in the last twenty-five years," Marine Geology, vol. 346, pp. 400-402, 2013.

[40] S. K. Wilson, A. M. Dolman, A. J. Cheal, M. J. Emslie, M. S. Pratchett, and H. P. A. Sweatman, "Maintenance of fish diversity on disturbed coral reefs," Coral Reefs, vol. 28, no. 1, pp. 3-14, 2009. 
[41] B. C. Congdon, C. A. Erwin, D. R. Peck, G. B. Baker, M. C. Double, and P. O'Neill, "Vulnerability of seabirds on the GBR to climate change," in Climate Change and the Great Barrier Reef: A Vulnerability Assessment, J. E. Johnson and P. A. Marshall, Eds., pp. 427-463, Great Barrier Reef Marine Park Authority, Australia, 2007.

[42] C. A. Devney, M. Short, and B. C. Congdon, "Cyclonic and anthropogenic influences on tern populations," Wildlife Research, vol. 36, no. 5, pp. 368-378, 2009.

[43] C. A. Devney, M. Julian Caley, and B. C. Congdon, "Plasticity of noddy parents and offspring to sea-surface temperature anomalies," PLoS One, vol. 5, no. 7, Article ID el1891, 2010.

[44] B. D. Russell, J.-A. I. Thompson, L. J. Falkenberg, and S. D. Connell, "Synergistic effects of climate change and local stressors: $\mathrm{CO}_{2}$ and nutrient-driven change in subtidal rocky habitats," Global Change Biology, vol. 15, no. 9, pp. 2153-2162, 2009.

[45] M. Byrne, "Impact of ocean warming and ocean acidification on marine invertebrate life history stages: vulnerability and potential for persistance in a changing ocean," in Oceanography \& Marine Biology, R. N. Gibson, R. J. A. Atkinson, and J. D. M. Gordon, Eds., vol. 49 of Oceanography and Marine Biology: An Annual Review, pp. 1-42, 2011.

[46] M. Byrne, M. Ho, E. Wong et al., "Unshelled abalone and corrupted urchins: development of marine calcifiers in a Changing Ocean," Proceedings of the Royal Society B, vol. 278, no. 1716, pp. 2376-2383, 2011.

[47] R. Berkelmans, G. De’ath, S. Kininmonth, and W. J. Skirving, "A comparison of the 1998 and 2002 coral bleaching events on the Great Barrier Reef: spatial correlation, patterns, and predictions," Coral Reefs, vol. 23, no. 1, pp. 74-83, 2004.

[48] J. Oliver and R. Berkelmans, "Patterns of coral bleaching on the Great Barrier Reef," in Coral Bleaching: Patterns, Processes, Causes and Consequences, M. J. H. van Oppen and J. M. Lough, Eds., vol. 205 of Ecological Studies, p. 192, Springer, Heidelberg, Germany, 2009.

[49] A. Baird and V. McGrath, "Coral bleaching on Thursday Island and environs in 2010," Report to the Torres Strait Regional Authority, Queensland, Australia, 2011.

[50] O. Hoegh-Guldberg, P. J. Mumby, A. J. Hooten et al., "Coral reefs under rapid climate change and ocean acidification," Science, vol. 318, no. 5857, pp. 1737-1742, 2007.

[51] P. G. Cardoso, D. Raffaelli, and M. A. Pardal, "The impact of extreme weather events on the seagrass Zostera noltii and related Hydrobia ulvae population," Marine Pollution Bulletin, vol. 56, no. 3, pp. 483-492, 2008.

[52] G. De'ath, J. M. Lough, and K. E. Fabricius, "Declining coral calcification on the Great Barrier Reef," Science, vol. 323, no. 5910, pp. 116-119, 2009.

[53] K. E. Fabricius, C. Langdon, S. Uthicke et al., "Losers and winners in coral reefs acclimatized to elevated carbon dioxide concentrations," Nature Climate Change, vol. 1, pp. 165-169, 2011.

[54] M. Turner and G. N. Batianoff, "Vulnerability of island flora and fauna in the Great Barrier Reef to climate change," in Climate Change and the Great Great Barrier Reef: A Vulnerability Assessment, J. E. Johnson and P. A. Marshall, Eds., pp. 622666, Great Barrier Reef Marine Park Authority, Australian Government, Townsville, Australia, 2007.

[55] J. L. Dawson and S. G. Smithers, "Shoreline and beach volume change between 1967 and 2007 at Raine Island, Great Barrier Reef, Australia," Global and Planetary Change, vol. 72, no. 3, pp. 141-154, 2010.
[56] M. M. P. B. Fuentes, J. A. Maynard, M. Guinea, I. P. Bell, P. J. Werdell, and M. Hamann, "Proxy indicators of sand temperature help project impacts of global warming on sea turtles in northern Australia," Endangered Species Research, vol. 9, no. 1, pp. 33-40, 2009.

[57] M. M. P. B. Fuentes, C. J. Limpus, and M. Hamann, "Vulnerability of sea turtle nesting grounds to climate change," Global Change Biology, vol. 17, no. 1, pp. 140-153, 2011.

[58] H. Yamano, K. Sugihara, and K. Nomura, "Rapid poleward range expansion of tropical reef corals in response to rising sea surface temperatures," Geophysical Research Letters, vol. 38, no. 4, Article ID L04601, 2011.

[59] P. M. Groffman, J. S. Baron, T. Blett et al., "Ecological thresholds: the key to successful environmental management or an important concept with no practical application?" Ecosystems, vol. 9, no. 1, pp. 1-13, 2006.

[60] P. G. Harnik, H. K. Lotze, S. C. Anderson et al., "Extinctions in ancient and modern seas," Trends in Ecology \& Evolution, vol. 27, pp. 608-617, 2012.

[61] J. P. Steffensen, K. K. Andersen, M. Bigler et al., "Highresolution Greenland ice core data show abrupt climate change happens in few years," Science, vol. 321, no. 5889, pp. 680-684, 2008.

[62] M. McCulloch, S. Fallon, T. Wyndham, E. Hendy, J. Lough, and D. Barnes, "Coral record of increased sediment flux to the inner Great Barrier Reef since European settlement," Nature, vol. 421, no. 6924, pp. 727-730, 2003.

[63] M. Byrne, N. A. Soars, M. A. Ho et al., "Fertilization in a suite of coastal marine invertebrates from SE Australia is robust to near-future ocean warming and acidification," Marine Biology, vol. 157, no. 9, pp. 2061-2069, 2010.

[64] J. E. N. Veron, O. Hoegh-Guldberg, T. M. Lenton et al., "The coral reef crisis: the critical importance of $<350 \mathrm{ppm} \mathrm{CO}_{2}$," Marine Pollution Bulletin, vol. 58, no. 10, pp. 1428-1436, 2009.

[65] G. P. Griffith, E. A. Fulton, R. Gorton, and A. J. Richardson, "Predicting interactions among fishing, ocean warming, and ocean acidification in a marine system with whole-ecosystem models," Conservation Biology, vol. 26, no. 6, pp. 1145-1152, 2012.

[66] P. W. Glynn and L. D'Croz, "Experimental evidence for high temperature stress as the cause of El Niño-coincident coral mortality," Coral Reefs, vol. 8, no. 4, pp. 181-191, 1990.

[67] C. Eakin, J. M. Lough, and S. F. Heron, "Climate variability and change: monitoring data and evidence for increased coral bleaching stress," in Coral Bleaching: Patterns and Processes, Causes and Consequences, M. van Oppen and J. Lough, Eds., vol. 205 of Ecological Studies, pp. 1-67, Springer, Heidelberg, Germany, 2009.

[68] J. A. Kleypas, J. W. McManu, and L. A. B. Mene, "Environmental limits to coral reef development: where do we draw the line?" American Zoologist, vol. 39, no. 1, pp. 146-159, 1999.

[69] S. J. Dalton and A. G. Carroll, "Monitoring coral health to determine coral bleaching response at high latitude eastern Australian Reefs: an applied model for a changing climate," Diversity, vol. 3, no. 4, pp. 592-610, 2011.

[70] A. P. Negri and M. O. Hoogenboom, "Water contamination reduces the tolerance of coral larvae to thermal stress," PLoS One, vol. 6, no. 5, Article ID e19703, 2011.

[71] A. P. Negri, F. Flores, T. Röthig, and S. Uthicke, "Herbicides increase the vulnerability of corals to rising sea surface temperature," Limnology and Oceanography, vol. 56, no. 2, pp. 471-485, 2011. 
[72] S. Uthicke, N. Vogel, J. Doyle, C. Schmidt, and C. Humphrey, "Interactive effects of climate change and eutrophication on the dinoflagellate-bearing benthic foraminifer Marginopora vertebralis," Coral Reefs, vol. 31, no. 2, pp. 401-414, 2012.

[73] S. A. Wooldridge and T. J. Done, "Improved water quality can ameliorate effects of climate change on corals," Ecological Applications, vol. 19, no. 6, pp. 1492-1499, 2009.

[74] J. Wiedenmann, S. D’Angelo, E. G. Smith et al., "Nutrient enrichment can increase the susceptibility of reef corals to bleaching," Nature Climate Change, vol. 3, pp. 160-164, 2012.

[75] T. P. Hughes, N. A. J. Graham, J. B. C. Jackson, P. J. Mumby, and R. S. Steneck, "Rising to the challenge of sustaining coral reef resilience," Trends in Ecology and Evolution, vol. 25, no. 11, pp. 633-642, 2010.

[76] J. F. Bruno, H. Sweatman, W. F. Precht, E. R. Selig, and V. G. W. Schutte, "Assessing evidence of phase shifts from coral to macroalgal dominance on coral reefs," Ecology, vol. 90, no. 6, pp. 1478-1484, 2009.

[77] M. Adjeroud, F. Michonneau, P. J. Edmunds et al., "Recurrent disturbances, recovery trajectories, and resilience of coral assemblages on a South Central Pacific reef," Coral Reefs, vol. 28, no. 3, pp. 775-780, 2009.

[78] T. M. Work, G. S. Aeby, and J. E. Maragos, "Phase shift from a coral to a corallimorph-dominated reef associated with a shipwreck on Palmyra Atoll," PLoS One, vol. 3, no. 8, Article ID e2989, 2008.

[79] S. R. Dudgeon, R. B. Aronson, J. F. Bruno, and W. F. Precht, "Phase shifts and stable states on coral reefs," Marine Ecology Progress Series, vol. 413, pp. 201-216, 2010.

[80] P. S. Petraitis and C. Hoffman, "Multiple stable states and relationship between thresholds in processes and states," Marine Ecology Progress Series, vol. 413, pp. 189-200, 2010.

[81] J. L. Davidson, I. E. van Putten, P. Leith, M. Nursey-Bray, E. M. Madin, and N. J. Holbrook, "Toward operationalizing resilience concepts in Australian marine sectors coping with climate change," Ecology \& Society, vol. 18, no. 3, article 4, 2013.

[82] N. A. J. Graham, T. D. Ainsworth, A. H. Baird et al., "From microbes to people: tractable benefits of no-take areas for coral reefs," Oceanography and Marine Biology, vol. 49, pp. 105-135, 2011.

[83] S. D. Ling and C. R. Johnson, "Marine reserves reduce risk of climate-driven phase shift by reinstating size- and habitatspecific trophic interactions," Ecological Applications, vol. 22, pp. 1232-1245, 2012.

[84] L. J. McCook, G. R. Almany, M. L. Berumen et al., "Management under uncertainty: guide-lines for incorporating connectivity into the protection of coral reefs," Coral Reefs, vol. 28, no. 2, pp. 353-366, 2009.

[85] E. Sanford and M. W. Kelly, "Local adaptation in marine invertebrates," Annual Review of Marine Science, vol. 3, pp. 509-535, 2011.

[86] Australian Department of the Environment, "Commonwealth Marine Reserves," 2013, http://www.environment.gov.au/marinereserves/.

[87] R. Pressey, "Australia's new marine protected areas: why they won't work," The Conversation, January 2013.

[88] P. L. Munday, J. M. Leis, J. M. Lough et al., "Climate change and coral reef connectivity," Coral Reefs, vol. 28, no. 2, pp. 379-395, 2009.

[89] A. Phillips, "Protected areas, and IUCN's world commission on protected areas (WCPA)- how can they help in the conservation of ferns?" Fern Gazette, vol. 16, no. 6-8, pp. 278-283, 2002.
[90] M. L. Baskett, R. M. Nisbet, C. V. Kappel, P. J. Mumby, and S. D. Gaines, "Conservation management approaches to protecting the capacity for corals to respond to climate change: a theoretical comparison," Global Change Biology, vol. 16, no. 4, pp. 12291246, 2010.

[91] J. R. Guest, A. H. Baird, J. A. Maynard et al., "Contrasting patterns of coral bleaching susceptibility in 2010 suggest an adaptive response to thermal stress," PLoS One, vol. 7, no. 3, Article ID e33353, 2012.

[92] T. E. Reed, D. E. Schindler, and R. S. Waples, "Interacting effects of phenotypic plasticity and evolution on population persistence in a changing climate," Conservation Biology, vol. 25, no. 1, pp. 56-63, 2011.

[93] S. K. Wilson, N. A. J. Graham, R. Fisher et al., "Effect of macroalgal expansion and marine protected areas on coral recovery following a climatic disturbance," Conservation Biology, vol. 26, pp. 995-1004, 2012.

[94] M. R. Myers and R. F. Ambrose, "Differences in benthic cover inside and outside marine protected areas on the Great Barrier Reef: influence of protection or disturbance history?" Aquatic Conservation: Marine and Freshwater Ecosystems, vol. 19, no. 7, pp. 736-747, 2009.

[95] E. R. Selig and J. F. Bruno, "A global analysis of the effectiveness of marine protected areas in preventing coral loss," PLoS One, vol. 5, no. 2, Article ID e9278, 2010.

[96] H. Sweatman, "No-take reserves protect coral reefs from predatory starfish," Current Biology, vol. 18, no. 14, pp. R598-R599, 2008.

[97] E. T. Game, E. McDonald-Madden, M. L. Puotinen, and H. P. Possingham, "Should we protect the strong or the weak? Risk, resilience, and the selection of marine protected areas," Conservation Biology, vol. 22, no. 6, pp. 1619-1629, 2008.

[98] E. A. Fulton, J. S. Link, I. C. Kaplan et al., "Lessons in modelling and management of marine ecosystems: the Atlantis experience," Fish and Fisheries, vol. 12, no. 2, pp. 171-188, 2011.

[99] E. A. Fulton, A. D. M. Smith, and A. E. Punt, "Which ecological indicators can robustly detect effects of fishing?" ICES Journal of Marine Science, vol. 62, no. 3, pp. 540-551, 2005.

[100] J. E. Johnson, J. A. Maynard, M. J. Devlin et al., "Resilience of Great Barrier Reef marine ecosystems and drivers of change," in Synthesis of Evidence to Support the Reef Water Quality Scientific Consensus Statement, chapter 2, Department of the Premier and Cabinet, Queensland Government, Brisbane, Australia, 2013.

[101] E. T. Game, M. E. Watts, S. Wooldridge, and H. P. Possingham, "Planning for persistence in marine reserves: a question of catastrophic importance," Ecological Applications, vol. 18, no. 3, pp. 670-680, 2008.

[102] C. Wilkinson and J. Brodie, "Catchment Management and Coral Reef Conservation: a practical guide for coastal resource managers to reduce damage from catchment areas," Global Coral Reef Monitoring Network and Reef and Rainforest Research Centre, Townsville, Australia, 2011.

[103] J. E. Brodie, J. Waterhouse, B. Schaffelke et al., "Scientific Consensus Statement: land use impacts on Great Barrier Reef water quality and ecosystem condition," Reef Water Quality Protection Plan, State of Queensland, Brisbane, Australia, 2013.

[104] A. S. Brierley and M. J. Kingsford, "Impacts of climate change on marine organisms and ecosystems," Current Biology, vol. 19, no. 14, pp. R602-R614, 2009.

[105] G.-R. Walther, "Community and ecosystem responses to recent climate change," Philosophical Transactions of the Royal Society B, vol. 365, no. 1549, pp. 2019-2024, 2010. 
[106] K. J. Willis, K. D. Bennett, S. A. Bhagwat, and H. J. B. Birks, "Perspective $4^{\circ} \mathrm{C}$ and beyond: what did this mean for biodiversity in the past?" Systematics and Biodiversity, vol. 8, no. 1, pp. 3-9, 2010.

[107] K. Brander, "Impacts of climate change on marine ecosystems and fisheries," Marine Biological Association India, vol. 51, no. 1, pp. 1-13, 2009.

[108] R. Q. Grafton, "Adaptation to climate change in marine capture fisheries," Marine Policy, vol. 34, no. 3, pp. 606-615, 2010.

[109] O. Hoegh-Guldberg, H. Hoegh-Guldberg, J. E. N. Veron et al., "The coral triangle and climate change: ecosystems, people and societies at risk," Coral Triangle Initiative, 2009.

[110] G. H. Rau, E. L. McLeod, and O. Hoegh-Guldberg, "The need for new ocean conservation strategies in a high-carbon dioxide world," Nature Climate Change, vol. 2, pp. 720-724, 2012.

[111] K. R. N. Anthony, J. A. Maynard, G. Diaz-Pulido et al., "Ocean acidification and warming will lower coral reef resilience," Global Change Biology, vol. 17, no. 5, pp. 1798-1808, 2011.

[112] T. Iwamura, K. A. Wilson, O. Venter, and H. P. Possingham, "A climatic stability approach to prioritizing global conservation investments," PLoS One, vol. 5, no. 11, Article ID e15103, 2010.

[113] D. O. Obura and G. Grimsditch, "Coral reefs, climate change and resilience: an agenda for action," IUCN Working Paper Series no. 5, IUCN World Conservation Congress, Barcelona, Spain, 2009.

[114] J. A. Maynard, P. A. Marshall, J. E. Johnson, and S. Harman, "Building resilience into practical conservation: identifying local management responses to global climate change in the southern Great Barrier Reef," Coral Reefs, vol. 29, no. 2, pp. 381391, 2010.

[115] C. M. Spillman, "Operational real-time seasonal forecasts for coral reef management," Journal of Operational Oceanography, vol. 4, no. 1, pp. 13-22, 2011.

[116] NOAA, "Coral Reef Watch," 2013, http://coralreefwatch.noaa .gov/satellite/index.php.

[117] CSIRO, “ReefTemp," 2013,http://www.cmar.csiro.au/remotesensing/reeftemp/web/index.htm.

[118] J. A. Maynard, J. E. Johnson, P. A. Marshall et al., "A strategic framework for responding to coral bleaching events in a changing climate," Environmental Management, vol. 44, pp. 1-11, 2009.

[119] W. W. L. Cheung, V. W. Y. Lam, J. L. Sarmiento, K. Kearney, R. Watson, and D. Pauly, "Projecting global marine biodiversity impacts under climate change scenarios," Fish and Fisheries, vol. 10, no. 3, pp. 235-251, 2009.

[120] C. J. Brown, E. A. Fulton, A. J. Hobday et al., "Effects of climatedriven primary production change on marine food webs: implications for fisheries and conservation," Global Change Biology, vol. 16, no. 4, pp. 1194-1212, 2010.

[121] M. Casini, J. Hjelm, J.-C. Molinero et al., "Trophic cascades promote threshold-like shifts in pelagic marine ecosystems," Proceedings of the National Academy of Sciences of the United States of America, vol. 106, no. 1, pp. 197-202, 2009.

[122] R. C. Carpenter, "Mass mortality of a Caribbean sea urchin: Immediate effects on community metabolism and other herbivores," Proceedings of the National Academy of Sciences USA, vol. 85, pp. 511-514, 1988.

[123] B. Planque, J.-M. Fromentin, P. Cury et al., "How does fishing alter marine populations and ecosystems sensitivity to climate?" Journal of Marine Systems, vol. 79, no. 3-4, pp. 403-417, 2010.
[124] A. J. Hobday, "Sliding baselines and shuffling species: implications of climate change for marine conservation," Marine Ecology, vol. 32, no. 3, pp. 392-403, 2011.

[125] B. Lausche, D. Farrier, J. Verschuuren et al., "The legal aspects of connectivity conservation,” A Concept Paper, IUCN, Gland, Switzerland, 2013.

[126] E. McLeod, R. Salm, A. Green, and J. Almany, "Designing marine protected area networks to address the impacts of climate change," Frontiers in Ecology and the Environment, vol. 7, no. 7, pp. 362-370, 2009.

[127] L. Hannah, G. Midgley, G. Hughes, and B. Bomhard, “The view from the cape: extinction risk, protected areas, and climate change," BioScience, vol. 55, no. 3, pp. 231-242, 2005.

[128] R. I. Mcdonald, P. Kareiva, and R. T. T. Forman, “The implications of current and future urbanization for global protected areas and biodiversity conservation," Biological Conservation, vol. 141, no. 6, pp. 1695-1703, 2008.

[129] E. T. Game, M. Bode, E. McDonald-Madden, H. S. Grantham, and H. P. Possingham, "Dynamic marine protected areas can improve the resilience of coral reef systems," Ecology Letters, vol. 12, no. 12, pp. 1336-1345, 2009.

[130] R. Trebilco, B. S. Halpern, J. M. Flemming, C. Field, W. Blanchard, and B. Worm, "Mapping species richness and human impact drivers to inform global pelagic conservation prioritisation," Biological Conservation, vol. 144, no. 5, pp. 1758-1766, 2011.

[131] T. L. Root and S. H. Schneider, "Conservation and climate change: the challenges ahead," Conservation Biology, vol. 20, no. 3, pp. 706-708, 2006.

[132] Global Environment Facility, 2013, http://www.thegef.org/gef/ node/10019.

[133] J. J. Lawler, "Climate change adaptation strategies for resource management and conservation planning," Annals of the New York Academy of Sciences, vol. 1162, pp. 79-98, 2009. 

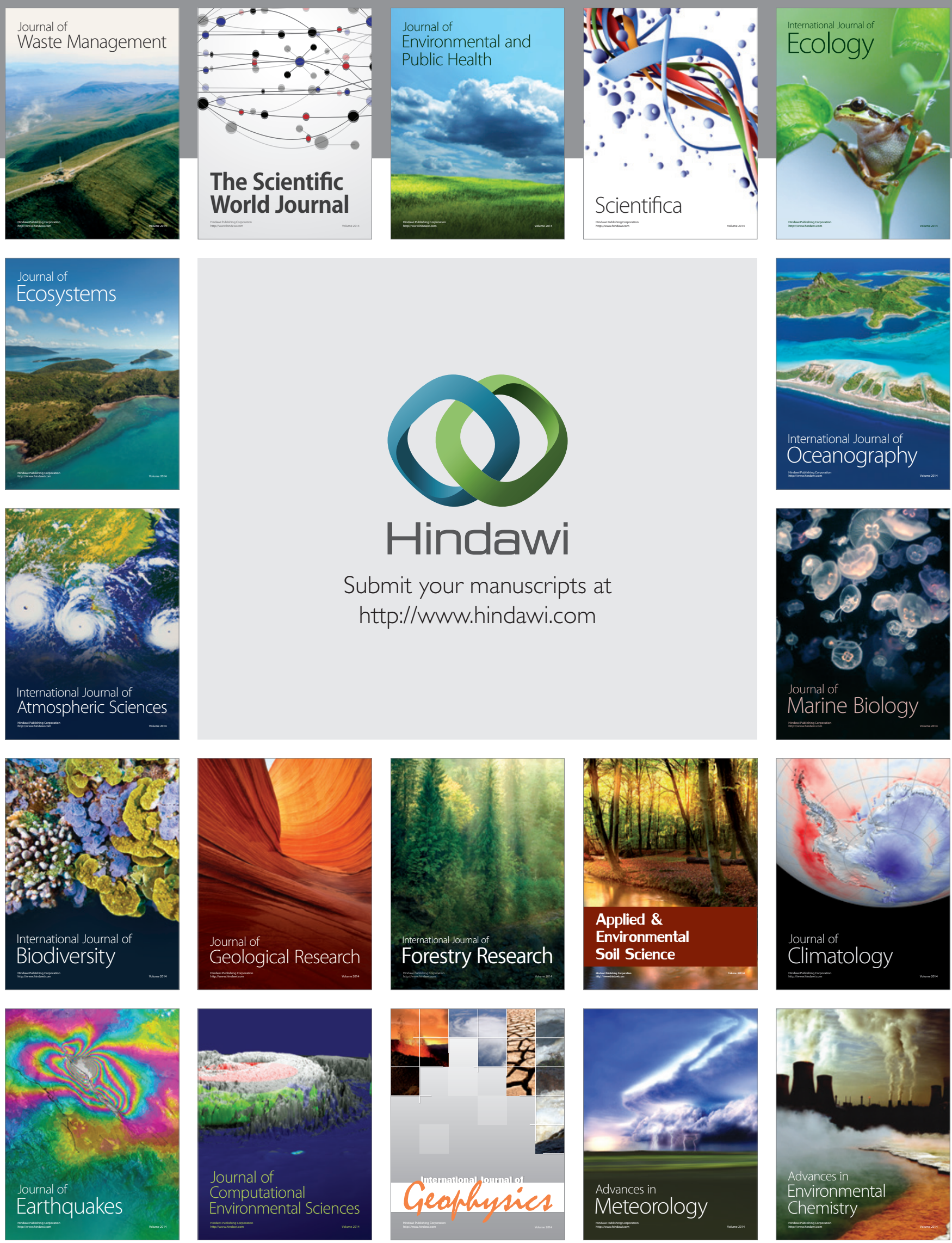